\title{
PENENTUAN PRIORITAS PENANGANAN JALAN DI KECAMATAN SEULIMEUM KABUPATEN ACEH BESAR DENGAN MENGUNAKAN ANALISIS MULTI KRITERIA
}

\author{
Fakhrurriza $^{1)}$, R. Anggraini ${ }^{2}$, M. Isya ${ }^{3)}$, \\ 1, 2, 3) Magister Teknik Sipil, Universitas Syiah Kuala, Banda Aceh

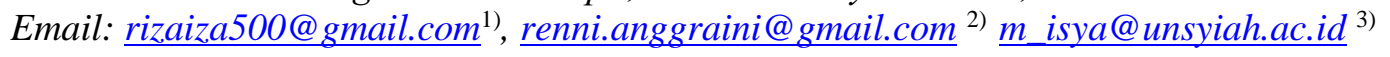

DOI: http://dx.doi.org/10.29103/tj.v11i2.487

(Received: February 2021 / Revised: March 2021 / Accepted: June 2021)

\begin{abstract}
Abstrak
Kecamatan Seulimeum merupakan kecamatan yang mempunyai tingkat kerusakan jalan yang paling berat diantara kecamatan lainnya yang ada di Kabupaten Aceh Besar. Jalan kabupaten di Kecamatan Seulimeum terdapat sebanyak 23 ruas dengan kondisi rusak berat sepanjang 69,50 km (50,44\%) dari 137,80 km. Mengingat Pemerintah Kabupaten Aceh Besar mempunyai keterbatasan anggaran pada sektor jalan, maka penanganan jalan di Kecamatan Seulimeum perlu dicarikan prioritas penanganan. Penelitian ini bertujuan untuk menganalisis kriteria yang dominan perlu dipertimbangkan dalam penanganan jalan dan menganalisis urutan prioritas penanganan jalan di Kecamatan Seulimeum. Penelitian ini menggunakan pendekatan metode kuantitatif melalui kuesioner. Teknik sampling yang digunakan adalah purposive sampling yaitu pengambilan sampel dengan pertimbangan yang didasarkan pada pihak pemangku kepentingan dan pengambil kebijakan (stakeholders) bidang jalan. Responden ditetapkan sebanyak 5 stakeholders yaitu Kepala Bidang Bina Marga Dinas Pekerjaan Umum dan Penataan Ruang (PUPR) Kabupaten Aceh Besar, Kepala Bidang Program Pembangunan Daerah Badan Perencanaan Pembangunan Daerah (Bappeda) Kabupaten Aceh Besar, Anggota Komisi IV Bidang Pembangunan Dewan Perwakilan Rakyat Kabupaten (DPRK) Aceh Besar, Camat Seulimeum, dan akademisi. Kriteria penanganan jalan yang ditinjau adalah kondisi jalan, tata guna lahan, aksesibilitas, kependudukan, fasilitas sosial, fasilitas pemerintahan, dan sarana perekonomian. Teknik analisis data digunakan Analisis Multi Kriteria (AMK). Hasil penelitian meunjukkan bahwa kriteria yang dominan perlu dipertimbangkan dalam penanganan jalan adalah kriteria kondisi jalan dengan nilai bobot kriteria rata-rata sebesar 0,323. Prioritas penanganan jalan adalah alternatif Jalan Seulimeum-Lamteuba sebagai prioritas 1 dengan kinerja alternatif sebesar 4,095, alternatif Jalan Entee Gajah-Lhieb sebagai prioritas 2 dengan kinerja alternatif sebesar 3,715, dan alternatif Jalan Lamteuba-Lamteuba Droe sebagai prioritas 3 dengan kinerja alternatif sebesar 3,619.
\end{abstract}

Kata kunci: Prioritas, penanganan, jalan, kriteria, alternatif, Kecamatan Seulimeum

\begin{abstract}
Seulimeum sub-district is a sub-district that has the heaviest level of road damage among other sub-districts in Aceh Besar District. There are 23 regency roads in Seulimeum District with severely damaged conditions along $69.50 \mathrm{~km}(50.44 \%)$ of $137.80 \mathrm{~km}$. Considering that the Aceh Besar District Government has a limited budget in the road sector, the handling of roads in Seulimeum District needs to be looked for priority handling. This study aims to analyze the dominant criteria that need to be considered in road handling and to analyze the priority order of road handling in
\end{abstract}

Penentuan Prioritas Penanganan Jalan di Kecamatan Seulimeum Kabupaten Aceh Besar Dengan Mengunakan Analisis Multi Kriteria - Fakhrurriza, R. Anggraini, M. Isya 


\begin{abstract}
Seulimeum District. This study uses a quantitative method approach through a questionnaire. The sampling technique used was purposive sampling, namely sampling with considerations based on the stakeholders and road sector stakeholders. The number of respondents was assigned as many as 5 stakeholders, namely the Head of Bina Marga Division of the Public Works and Spatial Planning (PUPR) of Aceh Besar District, Head of the Regional Development Program Division of the Regional Development Planning Agency (Bappeda) Aceh Besar District, Members of Commission IV for the Development Sector of the District People's Representative Council (DPRK) Aceh Besar, Head of Seulimeum sub-district, and academics. The road handling criteria reviewed are road conditions, land use, accessibility, population, social facilities, government facilities and economic facilities. The data analysis technique used Multi Criteria Analysis (MCA). The results showed that the dominant criterion that needs to be considered in road handling is the criteria for road conditions with an average criterion weight value of 0.323 . The road handling priority is the Seulimeum - Lamteuba road alternative as priority 1 with an alternative performance of 4.095 , the Entee Gajah - Lhieb road alternative as priority 2 with an alternative performance of 3.715 , and the alternative Jalan Lamteuba - Lamteuba Droe as priority 3 with an alternative performance of 3.619 .
\end{abstract}

Keywords: Priority, handling, roads, criteria, alternatives, Seulimeum District

\title{
1. Latar Belakang
}

Jalan merupakan prasarana transportasi untuk menghubungkan suatu tempat ke tempat lain. Jalan mempunyai peran strategis dalam mendukung pembangunan dan integrasi nasional sebagai bagian dari upaya untuk memajukan kesejahteraan umum, sebagaimana yang diamanatkan oleh Undang-undang Dasar Republik Indonesia Tahun 1945. Pembangunan jalan merupakan tanggung jawab yang diemban oleh pemerintah daerah. Jalan yang sudah dibangun oleh pemerintah daerah melalui rekanan, sering mengalami kerusakan atau kegagalan sebelum mencapai umur rencana. Kerusakan tersebut dapat berupa retak (cracking), distorsi (distortion), cacat permukaan (disintegration), pengausan (polished aggregate), kegemukan (bleeding), dan penurunan pada bekas penanaman utilitas. Sehubungan pentingnya peranan jalan, maka pemerintah daerah perlu melakukan kegiatan penanganan jalan pada sejumlah ruas jalan yang mempunyai kerusakan. Penanganan jalan adalah suatu kegiatan yang meliputi program pemeliharaan jalan, peningkatan jalan, dan konstruksi baru.

Kabupaten Aceh Besar mempunyai jalan kabupaten sebanyak 629 ruas yang tersebar di 23 kecamatan dengan total panjang 1.279,44 km. Jalan di Kabupaten Aceh Besar dengan kondisi baik mempunyai panjang 344,28 km (26,91\%), dengan kondisi sedang mempunyai panjang 334,34 km (26,13\%), dengan kondisi rusak ringan mempunyai panjang 193,04 $\mathrm{km}(15,09 \%)$ serta dengan kondisi rusak berat mempunyai panjang 407,79 km $(31,87 \%)$ (Data Dasar Prasarana Jalan Kabupaten Aceh Besar, 2019). Data tersebut memperlihatkan bahwa kondisi jalan di Kabupaten Aceh Besar didominasi oleh kondisi tidak mantap. Dominasi kondisi tidak mantap tersebut, dipengaruhi oleh keterbatasan anggaran Pemerintah Kabupaten Aceh Besar pada sektor jalan, sehingga tidak terselenggaranya penanganan jalan secara menyeluruh.

Kecamatan Seulimeum merupakan kecamatan yang mempunyai tingkat kerusakan jalan yang paling berat diantara kecamatan lainnya yang ada di wilayah administrasi Kabupaten Aceh Besar. Jalan kabupaten di Kecamatan Seulimeum terdapat sebanyak 34 ruas dengan total panjang $137,80 \mathrm{~km}$, di mana yang 
mempunyai kondisi rusak berat terdapat sebanyak 23 ruas dengan total panjang 69,50 km (50,44\%). Mengingat Pemerintah Kabupaten Aceh Besar tidak mampu menangani seluruh ruas yang ada dan mempunyai keterbatasan anggaran atau Dana Alokasi Khusus (DAK) pada sektor jalan, maka penanganan jalan di Kecamatan Seulimeum perlu dicarikan prioritas penanganan dengan mempertimbangkan beberapa kriteria. Beberapa kriteria yang sudah lazim ditinjau oleh peneliti terdahulu adalah seperti kriteria volume lalu lintas, kapasitas jalan, kecelakaan lalu lintas, ekonomi, kebijakan, kerusakan samping jalan, pengembangan wilayah, keterpaduan hirarki sistem jaringan jalan, keterpaduan antar moda transportasi, lingkungan, sosial, dan biaya pembangunan, oleh karena itu penentuan prioritas dalam penanganan jalan di Kecamatan Seulimeum mempertimbangkan beberapa kriteria yang belum ditinjau seperti kriteria kondisi jalan, tata guna lahan, aksesibilitas, kependudukan, fasilitas sosial, fasilitas pemerintahan, dan sarana perekonomian. Dengan mempertimbangkan beberapa kriteria tersebut, maka dapat diperoleh urutan prioritas penanganan jalan di Kecamatan Seulimeum yang tepat sasaran.

\section{Metode Penelitian}

\subsection{Objek dan Lokasi Penelitian}

Objek dalam penelitian ini adalah jalan kabupaten dengan kondisi rusak berat, lokasi penelitian terletak di jalan Kecamatan Seulimeum sebanyak 23 ruas dengan kondisi rusak berat yang terdaftar pada Data Dasar Prasarana Jalan (DD1) Kabupaten Aceh Besar.

\subsection{Teknik Penentuan Sampel}

Teknik penentuan sampel responden dan narasumber yang digunakan adalah purposive sampling yaitu teknik pengambilan sampel dengan pertimbangan tertentu yang didasarkan pada pemangku kepentingan dan pengambil kebijakan (stakeholders) bidang jalan. Dalam hal ini, jumlah sampel responden dan narasumber ditetapkan sebanyak 5 stakeholders yaitu Kepala Bidang Bina Marga Dinas PUPR Kabupaten Aceh Besar, Kepala Bidang Program Pembangunan Daerah Bappeda Kabupaten Aceh Besar, Anggota Komisi IV Bidang Pembangunan Dewan Perwakilan Rakyat Kabupaten (DPRK) Aceh Besar, Camat Seulimeum, dan akademisi Universitas Syiah Kuala.

\subsection{Teknik Pengumpulan Data Kuesioner}

Kuesioner bertujuan untuk menanyakan tentang perbandingan kriteria berpasangan secara parsial. Pengukuran jawaban menggunakan skala Saaty yaitu penilaian perbandingan berpasangan. Pengumpulan data kuesioner dilakukan dengan menjumpai langsung tempat keberadaan responden dan memberikan formulir kuesioner. Responden diminta untuk memilih jawaban yang telah disediakan dengan memberikan checklist $(\sqrt{ })$. Pembagian kuesioner dilakukan pendampingan, agar bila responden terdapat kendala dalam pengisian dapat diberikan penjelasan. Kuesioner yang telah diisi oleh responden selanjutnya dikumpulkan kembali. Pengumpulan data kuesioner dilakukan dalam rentang waktu 1 bulan.

Penentuan Prioritas Penanganan Jalan di Kecamatan Seulimeum Kabupaten Aceh Besar Dengan Mengunakan Analisis Multi Kriteria - Fakhrurriza, R. Anggraini, M. Isya 


\subsection{Teknik Analisis Data}

Analisis data menggunakan Analisis Multi Kriteria (AMK) merupakan alternatif teknik yang mampu menggabungkan sejumlah kriteria dengan besaran yang berbeda (multi variable) dan dalam persepsi pihak terkait yang bermacammacam (multi facet) (Supriadi et al., 2018). Hirarki AMK meliputi tujuan, kriteria, dan alternatif. Tujuannya adalah untuk mengidentifikasi kriteria yang dominan perlu dipertimbangkan dalam penanganan jalan dan untuk menentukan urutan prioritas penanganan jalan. Kriterianya adalah kondisi jalan, tata guna lahan, aksesibilitas, kependudukan, fasilitas sosial, fasilitas pemerintahan, dan sarana perekonomian. Justifikasi peneliti terhadap kriteria tersebut adalah sebagai berikut: 1. Kriteria kondisi jalan ditinjau dengan pertimbangan ruas jalan yang mempunyai kondisi buruk terpendek perlu diprioritaskan penanganan jalan, sehingga dapat memberikan pelayanan yang mantap bagi pengguna jalan.

2. Kriteria tata guna lahan ditinjau dengan pertimbangan ruas jalan yang melewati lahan produktif terluas perlu diprioritaskan penanganan jalan, sehingga hasil bumi banyak dapat diangkut oleh masyarakat.

3. Kriteria aksesibilitas ditinjau dengan pertimbangan ruas jalan yang mempunyai aksesibilitas tertinggi perlu diprioritaskan penanganan jalan, sehingga dapat mempermudah masyarakat dalam melakukan berbagai aktivitas di pusat kota kecamatan dan kabupaten.

4. Kriteria kependudukan ditinjau dengan pertimbangan ruas jalan yang melewati kependudukan terbanyak perlu diprioritaskan penanganan jalan, sehingga hajat hidup orang banyak dapat tercapai.

5. Kriteria fasilitas sosial ditinjau dengan pertimbangan ruas jalan yang melewati fasilitas sosial terbanyak perlu diprioritaskan penanganan jalan, sehingga masyarakat dapat mudah mengaksesnya.

6. Kriteria fasilitas pemerintahan ditinjau dengan pertimbangan ruas jalan yang melewati fasilitas pemerintahan terbanyak perlu diprioritaskan penanganan jalan, sehingga masyarakat dapat mudah mengaksesnya.

7. Kriteria sarana perekonomian ditinjau dengan pertimbangan ruas jalan yang melewati sarana perekonomian terbanyak perlu diprioritaskan penanganan jalan, sehingga dapat meningkatkan perputaran roda ekonomi.

Alternatifnya adalah meliputi Jalan Simpang Kayee Adang-Kayee Adang (A1), Jalan Lamteuba-Lamteuba Droe (A2), Jalan Jeurat Siputeh-Tanoh Abee (A3), Jalan Seulimeum-Lamteuba (A4), Jalan Iboh-Desa Teuladan (A5), Jalan Simpang Bayu-Gampong Ayon (A6), Jalan Entee Gajah-Lhieb (A7), Jalan Pasar Seulimeum-Alue Gintong (A8), Jalan Merlik-Iboh Tanjung (A9), Jalan Simpang Lamteuba-Lam Apeng (A10), Jalan Lamkleng-Lamcarak (A11), Jalan Lampisang Tunong-Data Gaseu (A12), Jalan Iboh Tanjong-Ayon (A13), Jalan Meunasah Baro-Alue Rindang (A14), Jalan Lamjruen-Iboh Tanjong (A15), Jalan Bayu-HTI (A16), Jalan Iboh Tanjong-Alue Rindang (A17), Jalan Lampisang Teungoh-Tutui (A18), Jalan Lam Apeng-Blang Ulam (A19), Jalan Leungah-Transmigrasi Leungah (A20), Jalan Simpang Lampanah-Lampanah (A21), Jalan Lampisang-Tanoh Abee (A22), dan Jalan Lamkabeu-Iboh (A23).

Adapun data kondisi seluruh kriteria terhadap 23 ruas jalan di Kecamatan Seulimeum dapat dilihat pada Tabel 1.

Penentuan Prioritas Penanganan Jalan di Kecamatan Seulimeum Kabupaten Aceh Besar Dengan Mengunakan Analisis Multi Kriteria - Fakhrurriza, R. Anggraini, M. Isya 
Tabel 1 Kondisi kriteria pada alternatif

\begin{tabular}{|c|c|c|c|c|c|c|c|c|c|c|c|c|c|c|c|c|c|c|c|}
\hline \multirow{3}{*}{$\begin{array}{c}\text { Altern } \\
\text { atif }\end{array}$} & \multicolumn{4}{|c|}{ Kriteria Kondisi Jalan (K1) } & \multicolumn{2}{|c|}{$\begin{array}{l}\text { Kriteria Tata } \\
\text { Guna Lahan } \\
\text { (K2) }\end{array}$} & \multicolumn{2}{|c|}{$\begin{array}{c}\text { Kriteria Aksesibilitas } \\
\text { (K3) }\end{array}$} & \multicolumn{2}{|c|}{$\begin{array}{c}\text { Kriteria } \\
\text { Aksesibilitas (K4) }\end{array}$} & \multicolumn{4}{|c|}{ Kriteria Fasilitas Sosial (K5) } & \multirow{3}{*}{$\begin{array}{c}\begin{array}{c}\text { Kriteria } \\
\text { Fasilitas } \\
\text { Pemerinta } \\
\text { han (K6) }\end{array} \\
\text { Balai } \\
\begin{array}{l}\text { Desa } \\
\text { (Unit) }\end{array}\end{array}$} & \multicolumn{4}{|c|}{ Kriteria Sarana Perekonomian (K7) } \\
\hline & \multicolumn{2}{|c|}{ Permukaan } & \multicolumn{2}{|c|}{ Kondisi Jalan } & \multirow[b]{2}{*}{$\begin{array}{l}\text { Lahan } \\
\text { Sawah } \\
(\mathrm{km2})\end{array}$} & \multirow[b]{2}{*}{$\begin{array}{l}\text { Lahan } \\
\text { Bukan } \\
\text { Sawah } \\
(\mathrm{km} 2)\end{array}$} & \multirow[b]{2}{*}{$\begin{array}{c}\text { Jarak ke } \\
\text { Ibu Kota } \\
\text { Kecamatan } \\
\quad(\mathrm{km})\end{array}$} & \multirow[b]{2}{*}{$\begin{array}{c}\text { Jarak ke } \\
\text { Ibu Kota } \\
\text { Kabupaten } \\
(\mathrm{km})\end{array}$} & \multirow[b]{2}{*}{$\begin{array}{c}\text { Jumlah } \\
\text { Penduduk } \\
\text { (Jiwa) }\end{array}$} & \multirow[b]{2}{*}{$\begin{array}{c}\text { Jumlah } \\
\text { Rumah } \\
\text { Tangga } \\
\text { (KK) }\end{array}$} & \multirow[b]{2}{*}{$\begin{array}{c}\text { Sekolah } \\
\text { (Unit) }\end{array}$} & \multirow[b]{2}{*}{$\begin{array}{c}\text { Fasilitas } \\
\text { Kesehatan } \\
\text { (Unit) }\end{array}$} & \multirow[b]{2}{*}{$\begin{array}{l}\text { Fasilitas } \\
\text { Ibadah } \\
\text { (Unit) }\end{array}$} & \multirow{2}{*}{$\begin{array}{c}\text { Fasilitas } \\
\text { Olahraga } \\
\text { (Unit) }\end{array}$} & & \multirow{2}{*}{$\begin{array}{l} \\
\text { Mini } \\
\text { Market } \\
\text { (Unit) }\end{array}$} & \multirow[b]{2}{*}{$\begin{array}{c}\text { Warung/ } \\
\text { Kedai } \\
\text { Makanan } \\
\text { Minuman } \\
\text { (Unit) }\end{array}$} & \multirow{2}{*}{$\begin{array}{c}\text { Pasar } \\
\text { dengan } \\
\text { Bangunan } \\
\text { Permanen } \\
\text { (Unit) }\end{array}$} & \multirow{2}{*}{$\begin{array}{c}\text { Pasar } \\
\text { dengan } \\
\text { Bangunan } \\
\text { Semi } \\
\text { Permanen } \\
\text { (Unit) }\end{array}$} \\
\hline & $\begin{array}{c}\text { Kerikil } \\
(\mathrm{km})\end{array}$ & $\begin{array}{l}\text { Tanah } \\
(\mathrm{km})\end{array}$ & $\begin{array}{l}\text { Rusak } \\
\text { Ringan } \\
(\mathrm{km})\end{array}$ & $\begin{array}{r}\text { Rusak } \\
\text { Berat } \\
(\mathrm{km})\end{array}$ & & & & & & & & & & & & & & & \\
\hline $\mathrm{A} 1$ & 1,0 & - & 0,5 & 1,0 & 0,6 & 1,7 & 4,5 & 22,5 & 1062 & 266 & 3 & 2 & 3 & 3 & 2 & 0 & 4 & 0 & 0 \\
\hline $\mathrm{A} 2$ & - & 0,7 & - & 2,0 & 10,8 & 18,5 & 58,5 & 91,5 & 3502 & 860 & 2 & 2 & 5 & 2 & 3 & 0 & 9 & 0 & 0 \\
\hline $\mathrm{A} 3$ & - & - & 0,5 & 0,7 & 1,5 & 0,4 & 20,9 & 69,9 & 1140 & 252 & 3 & 2 & 7 & 2 & 2 & 0 & 4 & 0 & 0 \\
\hline A4 & - & - & 0,8 & 0,8 & 12,0 & 12,6 & 44,0 & 149,8 & 6780 & 1382 & 6 & 2 & 15 & 10 & 3 & 1 & 26 & 1 & 1 \\
\hline A5 & 2,9 & 7,2 & - & 10,0 & 5,3 & 7,1 & 20,8 & 53,8 & 1750 & 437 & 1 & 0 & 5 & 4 & 2 & 0 & 3 & 0 & 0 \\
\hline A6 & - & - & 0,6 & 0,2 & 0,8 & 6,7 & 12,5 & 34,5 & 793 & 176 & 1 & 0 & 3 & 0 & 1 & 0 & 0 & 0 & 0 \\
\hline A7 & 2,6 & - & - & 2,6 & 0,8 & 5,6 & 1,5 & 12,5 & 769 & 171 & 0 & 0 & 2 & 0 & 0 & 0 & 1 & 0 & 0 \\
\hline A8 & - & - & 0,6 & 0,9 & 6,1 & 7,9 & 5,1 & 49,1 & 2971 & 686 & 5 & 0 & 8 & 5 & 2 & 1 & 11 & 1 & 1 \\
\hline A9 & 3,0 & - & - & 3,0 & 2,7 & 7,0 & 18,5 & 51,5 & 1169 & 274 & 1 & 0 & 4 & 1 & 2 & 0 & 0 & 0 & 0 \\
\hline A10 & 2,5 & - & - & 2,5 & 2,6 & 16,4 & 40,4 & 62,4 & 1306 & 351 & 3 & 1 & 2 & 3 & 0 & 0 & 5 & 0 & 0 \\
\hline A11 & 1,8 & 0,7 & - & 2,5 & 1,8 & 5,0 & 10,1 & 32,1 & 693 & 170 & 0 & 0 & 2 & 1 & 2 & 0 & 2 & 0 & 0 \\
\hline A12 & 3,0 & 2,6 & - & 5,6 & 2,0 & 10,7 & 16,3 & 41,9 & 2189 & 478 & 2 & 0 & 5 & 1 & 2 & 0 & 5 & 0 & 0 \\
\hline $\mathrm{A} 13$ & 0,7 & - & - & 0,7 & 2,3 & 4,3 & 12,5 & 34,5 & 728 & 175 & 0 & 0 & 3 & 1 & 2 & 0 & 0 & 0 & 0 \\
\hline A14 & 1,4 & - & 0,8 & 0,6 & 10,4 & 6,8 & 14,7 & 35,7 & 1629 & 333 & 0 & 0 & 5 & 3 & 1 & 0 & 4 & 0 & 0 \\
\hline A15 & 1,7 & - & - & 1,7 & 3,4 & 0,5 & 7,3 & 27,9 & 761 & 184 & 0 & 0 & 2 & 1 & 1 & 0 & 1 & 0 & 0 \\
\hline A16 & 4,1 & - & 2,7 & 4,1 & 3,7 & 9,1 & 25,5 & 69,5 & 1553 & 372 & 2 & 0 & 5 & 2 & 2 & 0 & 0 & 0 & 0 \\
\hline A17 & - & - & 0,2 & 0,9 & 5,3 & 7,1 & 20,8 & 53,8 & 1750 & 437 & 1 & 0 & 5 & 4 & 2 & 0 & 3 & 0 & 0 \\
\hline A18 & 2,9 & - & - & 2,9 & 1,3 & 4,7 & 19,5 & 55,5 & 1659 & 364 & 2 & 0 & 4 & 1 & 3 & 0 & 0 & 0 & 0 \\
\hline A19 & 12,9 & - & - & 12,9 & 0,7 & 14,0 & 70,3 & 92,3 & 993 & 237 & 1 & 0 & 3 & 1 & 0 & 0 & 3 & 0 & 0 \\
\hline A20 & 7,5 & - & - & 7,5 & 0,4 & 9,9 & 56,0 & 67,0 & 840 & 221 & 2 & 0 & 2 & 1 & 1 & 0 & 2 & 0 & 0 \\
\hline A21 & 1,3 & - & - & 1,3 & 0,1 & 1,1 & 37,3 & 48,3 & 264 & 68 & 0 & 0 & 1 & 0 & 0 & 0 & 0 & 0 & 0 \\
\hline A22 & 0,8 & - & - & 0,8 & 1,4 & 4,7 & 13,4 & 42,4 & 1320 & 270 & 1 & 0 & 4 & 1 & 3 & 0 & 0 & 0 & 0 \\
\hline $\mathrm{A} 23$ & 4,6 & - & - & $\begin{array}{l}, 6 \\
4,6\end{array}$ & 7,7 & $\begin{array}{l}3, r \\
3,7\end{array}$ & 7,3 & $\begin{array}{r}4,47 \\
3,7\end{array}$ & 1688 & 426 & 2 & 2 & 5 & 3 & 1 & 0 & 1 & 0 & 0 \\
\hline
\end{tabular}
berikut:

Analisis Multi Kriteria (AMK) mempunyai beberapa tahapan yaitu sebagai

1. Membuat matriks perbandingan kriteria berpasangan

Matriks perbandingan kriteria berpasangan berguna untuk mendapatkan sejumlah ouput seperti eigen vector (Wi), bobot kriteria $(\mathrm{Xi})$, eigen value ( $\chi$ maks), indeks konsistensi $(\mathrm{CI})$, dan rasio konsistensi (CR). Output tersebut dihitung dengan cara sebagai berikut:

a. Wi dihitung dengan menggunakan Persamaan

$W i=\sqrt[n]{\text { ai1 } \mathrm{x} \text { ai } 2 \times \ldots \times \text { aij }}$

di mana:

$\mathrm{Wi}=$ Eigen vector kriteria $\mathrm{I}$

a i1 = Perbandingan tingkat kepentingan kriteria i terhadap kriteria 1

ai2 $=$ Perbandingan tingkat kepentingan kriteria i terhadap kriteria 2

aij $=$ Perbandingan tingkat kepentingan kriteria $\mathrm{i}$ terhadap kriteria $\mathrm{j}$

$\mathrm{n}=$ Jumlah kriteria

b. Xi dihitung dengan menggunakan Persamaan

$$
X i=\frac{\mathrm{Wi}}{\sum \mathrm{Wi}}
$$

c. $\chi$ maks dihitung dengan menggunakan Persamaan

$\chi_{\text {maks }}=\sum$ (aij $\mathrm{x}$ xij)

di mana:

$\chi_{\text {maks }}=$ Nilai eigen maksimum

$\mathrm{a}_{\mathrm{ij}} \quad=$ Perbandingan tingkat kepentingan kriteria $i$ terhadap kriteria $j$

$\mathrm{x}_{\mathrm{ij}} \quad=$ Eigen vector pada masing-masing kriteria $i$ terhadap kriteria $j$

Penentuan Prioritas Penanganan Jalan di Kecamatan Seulimeum Kabupaten Aceh Besar Dengan Mengunakan Analisis Multi Kriteria - Fakhrurriza, R. Anggraini, M. Isya 
d. CI dihitung dengan menggunakan Persamaan

$$
\mathrm{CI}=\frac{\lambda \text { maks }-\mathrm{n}}{\mathrm{n}-1}
$$

di mana:

$$
\begin{array}{ll}
\mathrm{CI} & =\text { Indeks konsistensi } \\
\chi_{\text {maks }} & =\text { Nilai } \text { eigen maksimum } \\
\mathrm{n} & =\text { Ukuran matriks }
\end{array}
$$

e. CR dihitung dengan menggunakan Persamaan

$$
\mathrm{CR}=\frac{\mathrm{CI}}{\mathrm{RI}}<0,1
$$

di mana:

$\mathrm{CR}=$ Rasio konsistensi

$\mathrm{CI}=$ Indeks konsistensi

$\mathrm{RI}=$ Indeks random, yang dapat dilihat pada Tabel 2.

Tabel 2 Nilai Indeks Random (IR)

\begin{tabular}{lcccccccccccc}
\hline $\begin{array}{l}\text { Ukuran } \\
\text { Matriks }\end{array}$ & 1,2 & 3 & 4 & 5 & 6 & 7 & 8 & 9 & 10 & 11 & 12 & 13 \\
\hline $\begin{array}{l}\text { Indeks } \\
\text { Random }\end{array}$ & 0,00 & 0,58 & 0,90 & 1,12 & 1,24 & 1,32 & 1,41 & 1,45 & 1,49 & 1,51 & 1,48 & 1,56 \\
\hline
\end{tabular}

Sumber: Saaty (1994)

Setelah memastikan semua persepsi responden konsisten melalui CR, maka Xi yang telah diperoleh sebelumnya dapat digunakan dan dihitung nilai rata-rata Xi. Nilai rata-rata $\mathrm{Xi}$ dihitung dengan cara nilai $\mathrm{Xi}$ antar responden dijumlahkan lalu dibagi dengan jumlah responden (5). Nilai rata-rata Xi tertinggi menunjukkan kriteria yang dominan perlu dipertimbangkan dalam penanganan jalan di Kecamatan Seulimeum.

2. Mengevaluasi kinerja alternatif pada masing-masing kriteria

Evaluasi kinerja alternatif pada masing-masing kriteria berguna untuk mengetahui kinerja 23 ruas jalan di Kecamatan Seulimeum terhadap kriteria kondisi jalan, tata guna lahan, aksesibilitas, kependudukan, fasilitas sosial, fasilitas pemerintahan, dan sarana perekonomian. Skor kinerja alternatif pada masing-masing kriteria dihitung dengan menggunakan Persamaan (6).

$$
\text { Skor Kinerja } X=\frac{\text { Nimai variabel } \mathrm{X}}{\text { Nilai variabel terbaik }} x 10
$$

Kriteria yang mempunyai beberapa sub kriteria, maka skor kinerja alternatif perlu dicarikan rata-rata.

3. Membuat matriks kinerja alternatif

Matriks kinerja alternatif berguna untuk mendapatkan kinerja alternatif (Pi) untuk masing-masing ruas jalan. Penentuan urutan prioritas dilakukan dengan cara mengalikan nilai rata-rata bobot kriteria (Xi) dengan nilai skor kinerja ratarata alternatif pada masing-masing kriteria. Hasil perkalian tersebut setelah 
dijumlahkan semua akan diperoleh kinerja alternatif (Pi). Pi tertinggi hingga terendah menunjukkan ruas jalan yang menjadi urutan prioritas penanganan di Kecamatan Seulimeum.

\section{Hasil dan Pembahasan}

\subsection{Matriks Perbandingan Kriteria Berpasangan}

Matriks perbandingan kriteria berpasangan digunakan untuk memetakan nilai skala dari persepsi responden terhadap kriteria yang perlu dipertimbangkan dalam penanganan jalan di Kecamatan Seulimeum. Perletakan nilai skala pada matriks perbandingan kriteria berpasangan dilakukan berdasarkan persepsi responden. Matriks perbandingan kriteria berpasangan pada dasarnya bertujuan untuk mendapatkan nilai bobot kriteria (Xi). Sebelum nilai digunakan lebih lanjut, maka perlu memastikan seluruh persepsi responden mempunyai jawaban yang konsisten, di mana nilai rasio konsistensi $(\mathrm{CR})$ harus $<0,1$. Adapun rekapitulasi nilai $\mathrm{CR}$ kriteria untuk masing-masing responden dapat dilihat pada Tabel 3.

Tabel 3 Rekapitulasi nilai CR

\begin{tabular}{llccc}
\hline No. & \multicolumn{2}{c}{ Responden } & CR $\leq 0,1$ & $\begin{array}{c}\text { Keteranga } \\
\text { n }\end{array}$ \\
\hline 1 & $\begin{array}{l}\text { Kepala Bidang Bina Marga Dinas PUPR } \\
\text { Kabupaten Aceh Besar }\end{array}$ & 0,093 & Konsisten \\
\hline 2 & $\begin{array}{l}\text { Kepala Bidang Program Pembangunan Daerah } \\
\text { Bappeda Kabupaten Aceh Besar }\end{array}$ & 0,095 & Konsisten \\
\hline 3 & $\begin{array}{l}\text { Anggota Komisi IV Bidang Pembangunan DPRK } \\
\text { Aceh Besar }\end{array}$ & 0,085 & Konsisten \\
\hline 4 & Camat Seulimeum & 0,095 & Konsisten \\
\hline 5 & Akademisi Universitas Syiah Kuala & 0,094 & Konsisten \\
\hline
\end{tabular}

Tabel 3 memperlihatkan bahwa seluruh persepsi responden mempunyai nilai CR kriteria $<0,1$, sehingga seluruh persepsi responden dinyatakan konsisten dalam memberikan penilaian tingkat kepentingan antar kriteria. Selanjutnya nilai Xi dari seluruh responden, perlu dicarikan nilai rata-rata Xi. Adapun nilai rata-rata Xi dari seluruh responden dapat dilihat pada Tabel 4.

Tabel 4 Nilai rata-rata Xi

\begin{tabular}{clcccccc}
\hline \multirow{2}{*}{ No. } & \multirow{2}{*}{ Kriteria } & \multicolumn{5}{c}{ Nilai Rata-rata Xi dari Responden Nilai Rata-rata } \\
\cline { 3 - 7 } & & 1 & 2 & 3 & 4 & 5 & Xi \\
\hline 1 & Kondisi jalan (K1) & 0,29 & 0,33 & 0,30 & 0,36 & 0,34 & 0,323 \\
\hline 2 & Tata guna lahan (K2) & 0,15 & 0,12 & 0,15 & 0,11 & 0,16 & 0,138 \\
\hline 3 & Aksesibilitas (K3) & 0,28 & 0,32 & 0,30 & 0,31 & 0,30 & 0,304 \\
\hline 4 & Kependudukan (K4) & 0,13 & 0,10 & 0,12 & 0,11 & 0,10 & 0,113 \\
\hline 5 & Fasilitas sosial (K5) & 0,06 & 0,05 & 0,06 & 0,05 & 0,05 & 0,054 \\
\hline 6 & Fasilitas pemerintahan (K6) & 0,03 & 0,02 & 0,03 & 0,02 & 0,02 & 0,024 \\
\hline 7 & Sarana perekonomian (K7) & 0,05 & 0,04 & 0,05 & 0,04 & 0,04 & 0,045 \\
\hline & Jumlah & 1,00 & 1,00 & 1,00 & 1,00 & 1,00 & 1,000 \\
\hline
\end{tabular}

Penentuan Prioritas Penanganan Jalan di Kecamatan Seulimeum Kabupaten Aceh Besar Dengan Mengunakan Analisis Multi Kriteria - Fakhrurriza, R. Anggraini, M. Isya 
Tabel 4 memperlihatkan bahwa nilai Xi tertinggi didapat pada kriteria kondisi jalan sebesar 0,323. Hal ini berarti bahwa kriteria yang dominan perlu dipertimbangkan dalam penanganan jalan di Kecamatan Seulimeum menurut persepsi stakeholders adalah kriteria kondisi jalan. Selain kriteria kondisi jalan, urutan kriteria lainnya yang perlu dipertimbangkan dalam penanganan jalan di Kecamatan Seulimeum menurut persepsi stakeholders adalah kriteria aksesibilitas dengan nilai Xi sebesar 0,304, kriteria tata guna lahan dengan nilai Xi sebesar 0,138, kriteria kependudukan dengan nilai Xi sebesar 0,113, kriteria fasilitas sosial dengan nilai Xi sebesar 0,054, kriteria sarana perekonomian dengan nilai Xi sebesar 0,045, dan kriteria fasilitas pemerintahan dengan nilai Xi sebesar 0,024. Hasil penelitian ini terdapat persamaan dengan 3 penelitian terdahulu yang relevan yaitu sebagai berikut:

1. Kriteria yang dominan perlu dipertimbangkan dalam pemeliharaan jalan kabupaten di wilayah perkotaan Tanjung Redeb adalah kriteria kondisi jalan dengan bobot sebesar 0,42 (Antoro et al., 2016).

2. Kriteria yang dominan perlu dipertimbangkan dalam penanganan jalan luar kota Kabupaten Pacitan adalah kriteria kondisi jalan dengan bobot sebesar 0,56 (Handayani et al., 2017).

3. Kriteria yang dominan perlu dipertimbangkan dalam penanganan jalan di Kabupaten Pidie adalah kriteria kerusakan jalan dengan bobot sebesar 0,197 (Thantawi, 2019).

Hasil penelitian ini terdapat perbedaan dengan 5 penelitian terdahulu yang relevan yaitu sebagai berikut:

1. Kriteria yang dominan perlu dipertimbangkan dalam penanganan ruas jalan nasional Bireuen-Lhokseumawe-Panton Labu adalah kriteria volume lalu lintas dengan bobot sebesar 0,386 (Risdiansyah et al., 2014).

2. Kriteria yang dominan perlu dipertimbangkan dalam pengembangan jaringan jalan pendukung Rencana Induk Pelabuhan (RIP) di Provinsi Aceh adalah kriteria efektifitas dalam mendukung pengembangan wilayah dengan bobot sebesar 0,438 (Ramli et al., 2017).

3. Kriteria yang dominan perlu dipertimbangkan dalam pembangunan jalan di Kabupaten Aceh Jaya adalah kriteria sosial dengan bobot sebesar 0,279 (Fuadi et al., 2018).

4. Kriteria yang dominan perlu dipertimbangkan dalam penanganan jalan di Kabupaten Timor Tengah Selatan adalah kriteria kawasan strategis dengan bobot sebesar 0,20 (Nope et al., 2018).

5. Kriteria yang dominan perlu dipertimbangkan dalam pemeliharaan jalan di Kabupaten Karanganyar adalah kriteria biaya penanganan dengan bobot sebesar 0,44 (Sushera et al., 2019).

\subsection{Evaluasi Kinerja Alternatif pada Masing-masing Kriteria}

Alternatif penanganan jalan di Kecamatan Seulimeum yang ditinjau dalam penelitian ini adalah Jalan Simpang Kayee Adang-Kayee Adang (A1), Jalan Lamteuba-Lamteuba Droe (A2), Jalan Jeurat Siputeh-Tanoh Abee (A3), Jalan Seulimeum-Lamteuba (A4), Jalan Iboh-Desa Teuladan (A5), Jalan Simpang BayuGampong Ayon (A6), Jalan Entee Gajah-Lhieb (A7), Jalan Pasar Seulimeum-Alue Gintong (A8), Jalan Merlik-Iboh Tanjung (A9), Jalan Simpang Lamteuba-Lam 
Apeng (A10), Jalan Lamkleng-Lamcarak (A11), Jalan Lampisang Tunong-Data Gaseu (A12), Jalan Iboh Tanjong-Ayon (A13), Jalan Meunasah Baro-Alue Rindang (A14), Jalan Lamjruen-Iboh Tanjong (A15), Jalan Bayu-HTI (A16), Jalan Iboh Tanjong-Alue Rindang (A17), Jalan Lampisang Teungoh-Tutui (A18), Jalan Lam Apeng-Blang Ulam (A19), Jalan Leungah-Transmigrasi Leungah (A20), Jalan Simpang Lampanah-Lampanah (A21), Jalan Lampisang-Tanoh Abee (A22), dan Jalan Lamkabeu-Iboh (A23). Setiap alternatif tersebut mempunyai kinerja tersendiri pada kriteria kondisi jalan (K1), kriteria tata guna lahan (K2), kriteria aksesibilitas (K3), kriteria kependudukan (K4), kriteria fasilitas sosial (K5), kriteria fasilitas pemerintahan (K6), dan kriteria sarana perekonomian (K7). Rekapitulasi kinerja alternatif pada masing-masing kriteria dapat dilihat pada Tabel 5.

Tabel 5 Rekapitulasi skor kinerja alternatif pada masing-masing kriteria

\begin{tabular}{lcccccccc}
\hline No. & Alternatif & $\begin{array}{c}\text { Skor } \\
\text { Kinerja } \\
\text { Rata-rata } \\
\text { K1 }\end{array}$ & $\begin{array}{c}\text { Skor } \\
\text { Kinerja } \\
\text { Rata-rata } \\
\text { K2 }\end{array}$ & $\begin{array}{c}\text { Skor } \\
\text { Kinerja } \\
\text { Rata-rata }\end{array}$ & $\begin{array}{c}\text { Skor } \\
\text { Kinerja }\end{array}$ & $\begin{array}{c}\text { Skor } \\
\text { Rata-rata } \\
\text { Kinerja }\end{array}$ & $\begin{array}{c}\text { Skor } \\
\text { Rata-rata } \\
\text { Kinerja K6 }\end{array}$ & $\begin{array}{c}\text { Kinerja } \\
\text { Rata-rata }\end{array}$ \\
\hline 1 & A1 & 3,13 & 0,71 & 4,44 & 1,75 & 5,00 & 6,67 & 0,38 \\
\hline 2 & A2 & 2,75 & 9,51 & 0,81 & 5,69 & 4,67 & 10,00 & 0,87 \\
\hline 3 & A3 & 1,83 & 0,72 & 1,25 & 1,75 & 5,42 & 6,67 & 0,38 \\
\hline 4 & A4 & 1,25 & 8,41 & 0,59 & 10,00 & 10,00 & 10,00 & 10,00 \\
\hline 5 & A5 & 0,85 & 4,13 & 1,52 & 2,87 & 2,25 & 6,67 & 0,29 \\
\hline 6 & A6 & 3,33 & 2,16 & 2,41 & 1,22 & 0,92 & 3,33 & 0,00 \\
\hline 7 & A7 & 0,82 & 1,85 & 10,00 & 1,19 & 0,33 & 0,00 & 0,10 \\
\hline 8 & A8 & 1,42 & 4,67 & 2,74 & 4,67 & 4,67 & 6,67 & 8,56 \\
\hline 9 & A9 & 0,71 & 2,99 & 1,62 & 1,85 & 1,33 & 6,67 & 0,00 \\
\hline 10 & A10 & 0,85 & 5,51 & 1,19 & 2,23 & 3,58 & 0,00 & 0,48 \\
\hline 11 & A11 & 3,61 & 2,09 & 2,69 & 1,13 & 0,58 & 6,67 & 0,19 \\
\hline 12 & A12 & 1,26 & 3,72 & 1,95 & 3,34 & 1,92 & 6,67 & 0,48 \\
\hline 13 & A13 & 3,27 & 2,12 & 2,41 & 1,17 & 0,75 & 6,67 & 0,00 \\
\hline 14 & A14 & 2,70 & 6,18 & 2,26 & 2,41 & 1,58 & 3,33 & 0,38 \\
\hline 15 & A15 & 1,29 & 1,54 & 3,27 & 1,23 & 0,58 & 3,33 & 0,10 \\
\hline 16 & A16 & 0,70 & 4,02 & 1,19 & 2,49 & 2,17 & 6,67 & 0,00 \\
\hline 17 & A17 & 3,06 & 4,13 & 1,52 & 2,87 & 2,25 & 6,67 & 0,29 \\
\hline 18 & A18 & 0,75 & 1,82 & 1,51 & 2,54 & 1,75 & 10,00 & 0,00 \\
\hline 19 & A19 & 0,16 & 4,08 & 0,78 & 1,59 & 1,17 & 0,00 & 0,29 \\
\hline 20 & A20 & 0,28 & 2,84 & 1,07 & 1,42 & 1,42 & 3,33 & 0,19 \\
\hline 21 & A21 & 1,70 & 0,33 & 1,50 & 0,44 & 0,17 & 0,00 & 0,00 \\
\hline 22 & A22 & 2,66 & 1,85 & 2,03 & 1,95 & 1,33 & 10,00 & 0,00 \\
\hline 23 & A23 & 0,46 & 4,03 & 1,59 & 2,79 & 4,92 & 3,33 & 0,10 \\
\hline
\end{tabular}

Tahap kedua AMK menginformasikan bahwa setiap kriteria mempunyai alternatif tersendiri yang perlu diprioritaskan dalam penanganan jalan di Kecamatan Seulimeum. Bila dilihat dari kriteria kondisi jalan (K1), penanganan jalan yang perlu diprioritaskan adalah alternatif Jalan Lamkleng-Lamcarak dengan skor kinerja rata-rata alternatif sebesar 3,61. Bila dilihat dari kriteria tata guna lahan (K2), penanganan jalan yang perlu diprioritaskan adalah alternatif Jalan LamteubaLamteuba Droe dengan skor kinerja rata-rata alternatif sebesar 9,51. Bila dilihat dari kriteria aksesibilitas (K3), penanganan jalan yang perlu diprioritaskan adalah alternatif Jalan Entee Gajah-Lhieb dengan skor kinerja rata-rata alternatif sebesar 10,00. Bila dilihat dari kriteria kependudukan (K4), kriteria fasilitas sosial (K5),

Penentuan Prioritas Penanganan Jalan di Kecamatan Seulimeum Kabupaten Aceh Besar Dengan Mengunakan Analisis Multi Kriteria - Fakhrurriza, R. Anggraini, M. Isya 
dan kriteria sarana perekonomian (K7), penanganan jalan yang perlu diprioritaskan adalah alternatif Jalan Seulimeum-Lamteuba dengan skor kinerja rata-rata alternatif sama-sama sebesar 10,00. Bila dilihat dari kriteria fasilitas pemerintahan (K6), penanganan jalan yang perlu diprioritaskan adalah alternatif Jalan Lamteuba Lamteuba Droe, alternatif Jalan Seulimeum-Lamteuba, alternatif Jalan Lampisang Teungoh-Tutui, dan alternatif Jalan Lampisang-Tanoh Abee dengan skor kinerja rata-rata alternatif sama-sama sebesar 10,00.

\subsection{Matriks Kriteria Alternatif}

Matriks kriteria alternatif digunakan untuk menentukan prioritas alternatif penanganan jalan di Kecamatan Seulimeum dengan mempertimbangkan beberapa kriteria. Penentuan prioritas alternatif dilakukan dengan mengalikan hasil Xi pada Tabel 4 dengan skor kinerja alternatif pada Tabel 5, lalu hasilnya dijumlahkan. Matriks kriteria alternatif penanganan jalan dapat diperlihatkan pada Tabel 6.

Tabel 6 Rekapitulasi skor kinerja alternatif pada masing-masing kriteria

\begin{tabular}{|c|c|c|c|c|c|c|c|c|c|c|c|c|c|c|c|c|c|}
\hline \multirow{4}{*}{ No. } & \multirow{4}{*}{ Alternatif } & \multirow{2}{*}{\multicolumn{2}{|c|}{$\begin{array}{c}\begin{array}{c}\text { Kondisi Jalan } \\
\text { (K1) }\end{array} \\
0,323 \\
\end{array}$}} & \multirow{2}{*}{\multicolumn{2}{|c|}{$\begin{array}{c}\begin{array}{c}\text { Tata Guna Lahan } \\
\text { (K2) }\end{array} \\
0,138 \\
\end{array}$}} & \multirow{2}{*}{\multicolumn{2}{|c|}{$\begin{array}{c}\begin{array}{c}\text { Aksesibilitas } \\
\text { (K3) }\end{array} \\
0,304 \\
\end{array}$}} & \multirow{2}{*}{\multicolumn{2}{|c|}{\begin{tabular}{|c|}
$\begin{array}{c}\text { Kependudukan } \\
\text { (K4) }\end{array}$ \\
0,113 \\
\end{tabular}}} & \multirow{2}{*}{\multicolumn{2}{|c|}{\begin{tabular}{|c}
$\begin{array}{c}\text { Fasilitas Sosial } \\
\text { (K5) }\end{array}$ \\
0,054 \\
\end{tabular}}} & \multirow{2}{*}{\multicolumn{2}{|c|}{$\begin{array}{c}\begin{array}{c}\text { Fasilitas } \\
\text { Pemerintahan } \\
\text { (K6) }\end{array} \\
0,024 \\
\end{array}$}} & \multirow{2}{*}{\multicolumn{2}{|c|}{$\begin{array}{c}\begin{array}{c}\text { Sarana } \\
\text { Perekonomian } \\
(\mathrm{K} 7)\end{array} \\
0,045 \\
\end{array}$}} & \multirow{4}{*}{$\begin{array}{l}\text { Kinerja } \\
\text { Alternatif } \\
\text { (Pi) }\end{array}$} & \multirow{4}{*}{ Prioritas } \\
\hline & & & & & & & & & & & & & & & & & \\
\hline & & $\begin{array}{c}\text { Skor } \\
\text { Kinerja }\end{array}$ & \multirow{2}{*}{$\begin{array}{c}\text { Hasil } \\
\text { Kali }\end{array}$} & $\begin{array}{c}\text { Skor } \\
\text { Kinerja }\end{array}$ & \multirow{2}{*}{$\begin{array}{c}\text { Hasil } \\
\text { Kali }\end{array}$} & $\begin{array}{l}\text { Skor } \\
\text { Kinerja }\end{array}$ & \multirow{2}{*}{$\begin{array}{l}\text { Hasil } \\
\text { Kali }\end{array}$} & $\begin{array}{l}\text { Skor } \\
\text { Kinerja }\end{array}$ & \multirow{2}{*}{$\begin{array}{c}\text { Hasil } \\
\text { Kali }\end{array}$} & $\begin{array}{c}\text { Skor } \\
\text { Kinerja }\end{array}$ & \multirow{2}{*}{$\begin{array}{l}\text { Hasil } \\
\text { Kali }\end{array}$} & $\begin{array}{l}\text { Skor } \\
\text { Kinerja }\end{array}$ & \multirow{2}{*}{$\begin{array}{c}\text { Hasil } \\
\text { Kali }\end{array}$} & $\begin{array}{c}\text { Skor } \\
\text { Kinerja }\end{array}$ & \multirow{2}{*}{$\begin{array}{c}\text { Hasil } \\
\text { Kali }\end{array}$} & & \\
\hline & & $\begin{array}{c}\text { Rata- } \\
\text { rata }\end{array}$ & & $\begin{array}{c}\text { Rata- } \\
\text { rata }\end{array}$ & & $\begin{array}{l}\text { Rata- } \\
\text { rata }\end{array}$ & & $\begin{array}{c}\text { Rata- } \\
\text { rata }\end{array}$ & & $\begin{array}{l}\text { Rata- } \\
\text { rata }\end{array}$ & & $\begin{array}{c}\text { Rata- } \\
\text { rata }\end{array}$ & & $\begin{array}{l}\text { Rata- } \\
\text { rata }\end{array}$ & & & \\
\hline 1 & A1 & 3,13 & 1,01 & 0,71 & 0,1 & 4,44 & 1,35 & 1,75 & 0,2 & 5 & 0,27 & 6,67 & 0,16 & 0,38 & 0,02 & 3,1 & 5 \\
\hline 2 & A 2 & 2,75 & 0,89 & 9,51 & 1,31 & 0,81 & 0,25 & 5,69 & 0,64 & 4,67 & 0,25 & 10 & 0,24 & 0,87 & 0,04 & 3,62 & 3 \\
\hline 3 & A3 & 1,83 & 0,59 & 0,72 & 0,1 & 1,25 & 0,38 & 1,75 & 0,2 & 5,42 & 0,29 & 6,67 & 0,16 & 0,38 & 0,02 & 1,73 & 17 \\
\hline 4 & A4 & 1,25 & 0,4 & 8,41 & 1,16 & 0,59 & 0,18 & 10 & 1,13 & 10 & 0,54 & 10 & 0,24 & 10 & 0,45 & 4,1 & 1 \\
\hline 5 & A5 & 0,85 & 0,27 & 4,13 & 0,57 & 1,52 & 0,46 & 2,87 & 0,32 & 2,25 & 0,12 & 6,67 & 0,16 & 0,29 & 0,01 & 1,92 & 13 \\
\hline 6 & A6 & 3,33 & 1,08 & 2,16 & 0,3 & 2,41 & 0,73 & 1,22 & 0,14 & 0,92 & 0,05 & 3,33 & 0,08 & 0 & 0 & 2,37 & 10 \\
\hline 7 & A7 & 0,82 & 0,26 & 1,85 & 0,26 & 10 & 3,04 & 1,19 & 0,13 & 0,33 & 0,02 & 0 & 0 & 0,1 & 0 & 3,72 & 2 \\
\hline 8 & A8 & 1,42 & 0,46 & 4,67 & 0,65 & 2,74 & 0,83 & 4,67 & 0,53 & 4,67 & 0,25 & 6,67 & 0,16 & 8,56 & 0,38 & 3,26 & 4 \\
\hline 9 & A9 & 0,71 & 0,23 & 2,99 & 0,41 & 1,62 & 0,49 & 1,85 & 0,21 & 1,33 & 0,07 & 6,67 & 0,16 & 0 & 0 & 1,57 & 19 \\
\hline 10 & $\mathrm{~A} 10$ & 0,85 & 0,27 & 5,51 & 0,76 & 1,19 & 0,36 & 2,23 & 0,25 & 3,58 & 0,19 & 0 & 0 & 0,48 & 0,02 & 1,86 & 15 \\
\hline 11 & A11 & 3,61 & 1,16 & 2,09 & 0,29 & 2,69 & 0,82 & 1,13 & 0,13 & 0,58 & 0,03 & 6,67 & 0,16 & 0,19 & 0,01 & 2,6 & 8 \\
\hline 12 & $\mathrm{~A} 12$ & 1,26 & 0,41 & 3,72 & 0,52 & 1,95 & 0,59 & 3,34 & 0,38 & 1,92 & 0,1 & 6,67 & 0,16 & 0,48 & 0,02 & 2,17 & 12 \\
\hline 13 & $\mathrm{~A} 13$ & 3,27 & 1,05 & 2,12 & 0,29 & 2,41 & 0,73 & 1,17 & 0,13 & 0,75 & 0,04 & 6,67 & 0,16 & 0 & 0 & 2,41 & 9 \\
\hline 14 & A14 & 2,7 & 0,87 & 6,18 & 0,85 & 2,26 & 0,69 & 2,41 & 0,27 & 1,58 & 0,09 & 3,33 & 0,08 & 0,38 & 0,02 & 2,87 & 6 \\
\hline 15 & A 15 & 1,29 & 0,42 & 1,54 & 0,21 & 3,27 & 0,99 & 1,23 & 0,14 & 0,58 & 0,03 & 3,33 & 0,08 & 0,1 & 0 & 1,87 & 14 \\
\hline 16 & $\mathrm{~A} 16$ & 0,7 & 0,23 & 4,02 & 0,56 & 1,19 & 0,36 & 2,49 & 0,28 & 2,17 & 0,12 & 6,67 & 0,16 & 0 & 0 & 1,7 & 18 \\
\hline 17 & A17 & 3,06 & 0,99 & 4,13 & 0,57 & 1,52 & 0,46 & 2,87 & 0,32 & 2,25 & 0,12 & 6,67 & 0,16 & 0,29 & 0,01 & 2,64 & 7 \\
\hline 18 & A18 & 0,75 & 0,24 & 1,82 & 0,25 & 1,51 & 0,46 & 2,54 & 0,29 & 1,75 & 0,09 & 10 & 0,24 & 0 & 0 & 1,57 & 20 \\
\hline 19 & $\mathrm{~A} 19$ & 0,16 & 0,05 & 4,08 & 0,56 & 0,78 & 0,24 & 1,59 & 0,18 & 1,17 & 0,06 & 0 & 0 & 0,29 & 0,01 & 1,11 & 22 \\
\hline 20 & A 20 & 0,28 & 0,09 & 2,84 & 0,39 & 1,07 & 0,32 & 1,42 & 0,16 & 1,42 & 0,08 & 3,33 & 0,08 & 0,19 & 0,01 & 1,13 & 21 \\
\hline 21 & A 21 & 1,7 & 0,55 & 0,33 & 0,05 & 1,5 & 0,45 & 0,44 & 0,05 & 0,17 & 0,01 & 0 & 0 & 0 & 0 & 1,11 & 23 \\
\hline 22 & $\mathrm{~A} 22$ & 2,66 & 0,86 & 1,85 & 0,26 & 2,03 & 0,62 & 1,95 & 0,22 & 1,33 & 0,07 & 10 & 0,24 & 0 & 0 & 2,26 & 11 \\
\hline 23 & A 23 & 0,46 & 0,15 & 4,03 & 0,56 & 1,59 & 0,48 & 2,79 & 0,31 & 4,92 & 0,27 & 3,33 & 0,08 & 0,1 & 0 & 1,85 & 16 \\
\hline
\end{tabular}

Tabel 6 memperlihatkan bahwa urutan prioritas penanganan jalan di Kecamatan Seulimeum berdasarkan kriteria kondisi jalan, tata guna lahan, aksesibilitas, kependudukan, fasilitas sosial, fasilitas pemerintahan, dan sarana perekonomian dari seluruh persepsi stakeholders adalah alternatif Jalan Seulimeum-Lamteuba (A4) sebagai prioritas 1 dengan Pi sebesar 4,095, alternatif Jalan Entee Gajah-Lhieb (A7) sebagai prioritas 2 dengan Pi sebesar 3,715, alternatif Jalan Lamteuba-Lamteuba Droe (A2) sebagai prioritas 3 dengan Pi sebesar 3,619, alternatif Jalan Peukan Seulimeum-Alue Gintong (A8) sebagai prioritas 4 dengan Pi sebesar 3,258, alternatif Jalan Simpang Kayee Adang-Kayee Adang (A1) sebagai prioritas 5 dengan Pi sebesar 3,098, alternatif Jalan Meunasah Baro-Alue Rindang 
(A14) sebagai prioritas 6 dengan Pi sebesar 2,867, alternatif Jalan Iboh TanjongAlue Rindang (A17) sebagai prioritas 7 dengan Pi sebesar 2,636, alternatif Jalan Lamkleng-Lamcarak (A11) sebagai prioritas 8 dengan Pi sebesar 2,595, alternatif Jalan Iboh Tanjong-Ayon (A13) sebagai prioritas 9 dengan Pi sebesar 2,412, alternatif Jalan Simpang Bayu-Gampong Ayon (A6) sebagai prioritas 10 dengan Pi sebesar 2,373, alternatif Jalan Lampisang-Tanoh Abee (A22) sebagai prioritas 11 dengan Pi sebesar 2,259, alternatif Jalan Lampisang Tunong-Data Gaseu (A12) sebagai prioritas 12 dengan Pi sebesar 2,174, alternatif Jalan Iboh-Desa Teuladan (A5) sebagai prioritas 13 dengan Pi sebesar 1,924, alternatif Jalan Lamjruen-Iboh Tanjong (A15) sebagai prioritas 14 dengan Pi sebesar 1,875, alternatif Jalan Simpang Lamteuba-Lam Apeng (A10) sebagai prioritas 15 dengan Pi sebesar 1,864, alternatif Jalan Lamkabeu-Iboh (A23) sebagai prioritas 16 dengan Pi sebesar 1,851, alternatif Jalan Jeurat Siputeh-Tanoh Abee (A3) sebagai prioritas 17 dengan Pi sebesar 1,735, alternatif Jalan Bayu-HTI (A16) sebagai prioritas 18 dengan Pi sebesar 1,701, alternatif Jalan Merlik-Iboh Tanjung (A9) sebagai prioritas 19 dengan Pi sebesar 1,573, alternatif Jalan Lampisang Teungoh-Tutui (A18) sebagai prioritas 20 dengan $\mathrm{Pi}$ sebesar 1,569, alternatif Jalan Leungah-Transmigrasi Leungah (A20) sebagai prioritas 21 dengan Pi sebesar 1,133, alternatif Jalan Lam Apeng-Blang Ulam (A19) sebagai prioritas 22 dengan Pi sebesar 1,110, dan alternatif Jalan Simpang Lampanah-Lampanah (A21) sebagai prioritas 23 dengan Pi sebesar 1,108.

\section{Kesimpulan dan Saran \\ 4.1 Kesimpulan}

Kriteria yang dominan perlu dipertimbangkan dalam penanganan jalan di Kecamatan Seulimeum adalah kriteria kondisi jalan dengan nilai bobot kriteria ratarata sebesar 0,323. Prioritas penanganan jalan di Kecamatan Seulimeum berdasarkan kriteria kondisi jalan, tata guna lahan, aksesibilitas, kependudukan, fasilitas sosial, fasilitas pemerintahan, dan sarana perekonomian adalah alternatif Jalan Seulimeum-Lamteuba sebagai prioritas 1 dengan kinerja alternatif sebesar 4,095, alternatif Jalan Entee Gajah-Lhieb sebagai prioritas 2 dengan kinerja alternatif sebesar 3,715, dan alternatif Jalan Lamteuba-Lamteuba Droe sebagai prioritas 3 dengan kinerja alternatif sebesar 3,619.

\subsection{Saran}

Peneliti selanjutnya yang melakukan penelitian relevan disarankan hendaknya dapat menambahkan lagi jumlah sampel, agar penentuan prioritas penanganan jalan dapat mengakomodir seluruh perspektif stakeholders terkait. Disarankan kepada peneliti selanjutnya yang melakukan penelitian relevan, agar dapat menggunakan analisis selain AMK seperti analytical network process.

\section{Daftar Kepustakaan}

Antoro, J.B., Djakfar, L., Wicaksono, A., 2016. Penentuan Prioritas Pemeliharaan Jalan Kabupaten di Wilayah Perkotaan Tanjung Redeb, Kabupaten Berau. Rekayasa Sipil 10, 1-9.

Penentuan Prioritas Penanganan Jalan di Kecamatan Seulimeum Kabupaten Aceh Besar Dengan Mengunakan Analisis Multi Kriteria - Fakhrurriza, R. Anggraini, M. Isya 
Data Dasar Prasarana Jalan Kabupaten Aceh Besar, 2019.

Fuadi, R., Isya, M., Anggraini, R., 2018. Analisa Skala Prioritas Proyek Pembangunan Jalan di Kabupaten Aceh Jaya. J. Arsip Rekayasa Sipil dan Perenc. 1, 22-29.

Handayani, D., Hartono, W., Firdausy, S., 2017. Prioritas Penanganan Jalan Luar Kota Kabupaten Pacitan. Matriks Tek. Sipil 5, 243-251.

Nope, F.J.S., Djakfar, L., Anwar, M.R., 2018. Model Prioritas Penanganan Jalan (Studi Kasus di Kabupaten Timor Tengah Selatan, NTT). JUTEKS J. Tek. Sipil 2, 149-157.

Ramli, M., Saleh, S.M., Anggraini, R., 2017. Studi Pengembangan Jaringan Jalan Pendukung Rencana Induk Pelabuhan (RIP) di Provinsi Aceh. J. Tek. Sipil Univ. Syiah Kuala 1, 143-156.

Risdiansyah, Isya, M., Saleh, S.M., 2014. Studi Penentuan Prioritas Penanganan Ruas Jalan Nasional Bireuen - Lhokseumawe - Panton Labu. J. Tek. Sipil Pascasarj. Univ. Syiah Kuala 3, 50-61.

Supriadi, A., Rustandi, A., Komarlina, D.H.L., Ardiani, G.T., 2018. Analytical Hierarchy Process (AHP) Teknik Penentuan Strategi Daya Saing Kerajinan Bordir. Deepublish, Yogyakarta.

Sushera, V., Rohman, M.A., Kartika, A.A.G., 2019. Analisis Prioritas Pemeliharaan Jalan Kabupaten Karanganyar Metode Analytical Hierarchy Process (AHP). J. Transp. Sist. Mater. dan Infrastruktur 1, 95-99.

Thantawi, 2019. Penentuan Skala Prioritas Penanganan Jalan Kabupaten Pidie Menggunakan Metode Analisis Multi Kriteria (AMK). Universitas Syiah Kuala. 